\title{
Service action research: review and guidelines
}

\author{
Mattias Elg \\ Department of Management and Engineering, Linköping University, Linköping, Sweden \\ Ida Gremyr \\ Department of Technology Management and Economics, Chalmers University of Technology, Göteborg, Sweden \\ Árni Halldórsson \\ Department of Technology Economics and Organization, Chalmers University of Technology, Gothenburg, Sweden and \\ Hanken School of Economics, Helsinki, Finland, and \\ Andreas Wallo \\ Department of Behavioural Sciences and Learning, Linköping University, Linköping, Sweden
}

\begin{abstract}
Purpose - Conducting research that is both practice- and theory-relevant is important for the service research community. Action research can be a fruitful approach for service researchers studying the transformative role of service research and wanting to make contributions to both the research community and to practical development. By exploring the current use of action research in service research, this study aims to make suggestions for enhancing the contribution to theory and practice development and to propose criteria for research quality for action research in service research.

Design/methodology/approach - This study builds on a systematic literature review of the use of action research approaches in service research. Findings - The study makes three main contributions. First, it posits that any action research project needs to consider the four elements of problem identification, theorization, creating guiding concepts and intervention. Second, based on these elements mirrored in service action research, it outlines and analyzes three approaches to action research (i.e. theory-enhancing, concept developing and practice-enhancing). Third, it suggests a move from instrumental to a more conceptual relevance of the research and elaborates on the criteria for research quality.

Originality/value - This study contributes to the understanding of how action research may be applied for conducting high-quality collaborative research in services and proposes measures to enhance research quality in action research projects focusing services.
\end{abstract}

Keywords Co-creation, Qualitative research, Marketing research

Paper type Literature review

\section{Introduction}

There is growing concern that academic research is losing its relevance and becoming less useful for solving practical problems (Van De Ven and Johnson, 2006). According to critics, academics are more focused on getting published than on making socially meaningful contributions (Alvesson et al., 2017). However, some also agree that the so-called collaborative research models, which often have an extensive interest in research utilization, tend to overly focus on practical interests, missing opportunities to produce theoretical knowledge (Herr and Anderson, 2005).

The problem of balancing research that is both practical- and theory-relevant is high on the agenda of the service research community (Gummesson and Gronroos, 2012). Recently, several papers on the scope, development and research priorities of service research have been published. These papers reference the transformative role of service research vis-à-vis management practice both by suggesting new research agendas (Ostrom et al., 2015; Brax and Visintin, 2017; Field et al., 2018;

The current issue and full text archive of this journal is available on Emerald Insight at: https://www.emerald.com/insight/0887-6045.htm

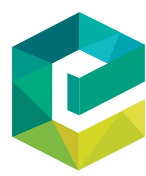

Journal of Services Marketing

34/1 (2020) 87-99

Emerald Publishing Limited [ISSN 0887-6045]

[DOI 10.1108/JSM-11-2018-0350]
Keating et al., 2018) and the need to enhance "theoretical advances and managerial usefulness" (Brodie and Gustafsson, 2016). Interestingly, while the new directions on what needs to be done in service research are explained in comprehensive terms, there is little debate on how the knowing-doing gap should be bridged.

Action research can be considered a fruitful approach for researchers studying the transformative role of service research and making contributions to both the research community and practical development (Gummesson and Gronroos, 2012). Action research, thus, has the potential to bridge the knowledge-doing gap through its "transformative orientation to knowledge creation," through which understanding and action are united, in the sense that researchers create new knowledge together with practitioners (Bradbury-Huang, 2010, p. 93). This implies spirals of action research cycles, including

(C) Mattias Elg, Ida Gremyr, Árni Halldórsson and Andreas Wallo. Published by Emerald Publishing Limited. This article is published under the Creative Commons Attribution (CC BY 4.0) licence. Anyone may reproduce, distribute, translate and create derivative works of this article (for both commercial and non-commercial purposes), subject to full attribution to the original publication and authors. The full terms of this licence may be seen at http://creativecommons.org/licences/by/4.0/ legalcode

Received 30 November 2018

Revised 12 July 2019

28 October 2019

Accepted 3 November 2019 
planning, action and observing (Ballantyne, 2004). These cycles provide a range of challenges for researchers engaged in action research. Keeping the new transformative, reoriented role of service research in mind, there is a need to move from the guidance that is given by the early proponents of action research (Gummesson, 2000) to the specific problems that are encountered by researchers in practical action research projects.

Service scholars have called for the increased use of action research (Gummesson, 2000; Gummesson and Gronroos, 2012), assuming greater proximity between researcher and practitioners. While this aligns well with the nature of services as being created in situ, limited attention has been paid to the usage of action research in the field of services. As action research has been criticized for a lack of academic rigor and limited contributions to theory (Svensson et al., 2007), a specific focus on research quality can enable future action research studies in service research to make contributions to theory and practice. By exploring the current use of action research in service research, this study aims to make suggestions for enhancing the contribution to theory and practice development and to propose criteria for research quality of action research in service research. This purpose is addressed by a literature review that is guided by the following research questions:

RQ1. How can the use of action research in service research be characterized?

RQ2. How is research quality addressed and further enhanced in action research studies in service research?

Based on these research questions, this study makes three main contributions. First, it posits that any action research project needs to consider four elements: problem identification, theorization, creating guiding concepts and intervention. Action research deals with all these elements implicitly or explicitly to various degrees. Second, based on these elements and the use of action research in service literature, this paper outlines and analyzes three types of approaches to action research (i.e. theory enhancing, concept developing and practice-enhancing). Third, this paper suggests a move from a mere instrumental to a more conceptual relevance of the research and an elaboration of the criteria for research quality to support this.

\section{Action research: an overview}

\subsection{Approaches and principles of action research}

The action research approach was founded by Kurt Lewin in the 1940 s to mobilize social science against authoritarian elements of society (Bradbury et al., 2008). For Lewin, the foundation of action research was the notion of the researcher's changing role from that of an external observer to a participant in concrete problem-solving and real-life issues (Greenwood and Levin, 1998). The Lewinian credo was if you think you understand a system, try to change it. Nielsen and Svensson (2006, p. 13) summarize one of the most central feature of action research: "There must be an action component; that is, the research should support a normative change in one way or another [...] while at the same time producing new knowledge." The link between action and new knowledge is secured through spiraling cycles of activities, including planning, acting, observing and reflecting, performed by a group of people who try to solve complex, practical problems (Perry and Gummesson, 2004). Thus, any action research project involves the elements of problem identification and theorization, which are the guiding concepts for dealing with the problem and intervention.

A central, and often debated, issue in action research is the role of the researcher in relation to the other active participants and the study object (Herr and Anderson, 2005). A common way to describe this role is that "action researchers are outside agents who act as facilitators of the action and reflection within an organisation" (Coughlan and Coghlan, 2002, p. 227). A counterpoint to this approach is the perspective of the professional who engages in research as an organizational insider. By being concerned with self-transformation and organizational development, the insider reflects and contributes to their organization and clients.

Action research aims to produce knowledge that is both practical and scientifically relevant and maintain a normative orientation concerned with issues such as organizational development, democratic processes, equality and emancipation. This is also echoed in service research, in which researchers called for more use of action research and participant observation (Gummesson et al., 2014; Corus and Saatcioglu, 2015). Fisk et al. (2016), for example, claim that community action research is "well suited" to study complex service systems, such as the "bottom of the pyramid." Such attention to proximity and engagement through action research is by no means new, and fields close to service research have already engaged in a methodological debate on this, including operations management (Coughlan and Coghlan, 2002), purchasing (Meehan et al., 2016; Bäckstrand and Halldórsson, 2019) and supply chain management (Touboulic and Walker, 2016).

According to Herr and Anderson (2005), the action researcher may be guided by both a performative intent to improve organizational practice or develop individuals and an intent to transform the practice itself by questioning established "truths" to reveal inequalities and identify power asymmetries, which is what Alvesson and Spicer (2012) call critical performativity. The sought-after knowledge in action research, thus, corresponds to Habermas's (1972) conceptualization of the three types of knowledge interests: the technical, practical/ hermeneutical and emancipatory (Herr and Anderson, 2005). The technical knowledge interest is the foundation for empirical, analytical science, and it urges finding and explaining natural laws and regularities. Practical interest has its place in the historical hermeneutic sciences that strive to interpret and understand human interaction. Finally, emancipatory interest is critical and seeks to show underlying power structures and ideologies.

How can we tell if an action research project has high quality? As with any research approach, conflicting and concurrent concepts aim to answer this question. The validity of action research derives from its ability to stay connected to the field and use this presence to evaluate and discuss results. A valid theory is not "added" by researchers, but is rather ideally created in the process of co-creation. However, it is important 
to underline that action research cannot ignore traditional validity requirements. Building upon Herr and Anderson (2005), the concept of validity is, in this paper, extended through an emphasis on the importance of reflective dialogue with the participants and other relevant actors in society to provide more trustworthy and robust knowledge.

For the purpose of this study, the next section develops a framework for analyzing previous action research studies in service research. The aim is to capture the various problems that researchers need to consider when engaging in action research.

\subsection{Analytical framework}

The analytical framework in this study allows for the characterization of various approaches to action research by contrasting different types of action research in terms of their interests in relation to two dimensions: research vs practice and problem vs solution. These two dimensions provide four different elements that action research projects need to address, either explicitly or implicitly (Figure 1). The analytical framework builds on the previously presented research challenges and the ideas of Van De Ven and Johnson's (2006) engaged scholarship and Svensson et al.'s (2015) model of interactive research.

First, the framework separates the research and the practice systems. Both of these systems are important to acknowledge, but distinction is also important because it highlights the risk that action research tends to emphasize the practical system (Eden and Huxham, 1996). Too much focus on the practice system with no, or very limited, connection to the research system is an often-posted critique against action research (Svensson et al., 2007). Issues and tasks in the research system, e.g. theorization, analytical understanding and creation of conceptual coherence (Miles and Huberman, 1994), differ from the interests in the practice system where practical knowledge and manifest deeds are the focus (Heron and Reason, 2001). What is interesting from the action researcher's point of view is that both systems need to be dealt with simultaneously.

Figure 1 Analytical framework: components and relations in AR

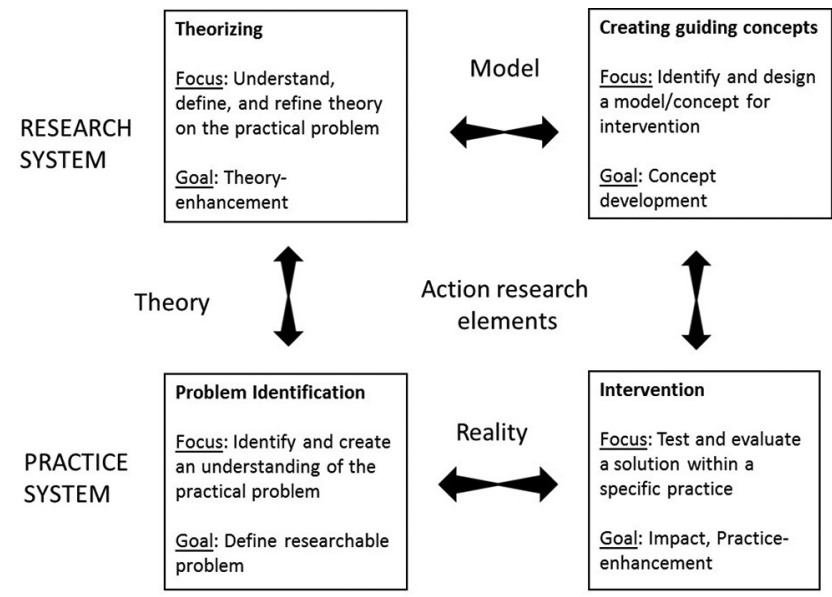

PROBLEM

SOLUTION
Second, the "problem vs solution" dimension implies that action research needs to address the magnitude, relevance and uncertainty of both the studied problem and the solutions that improve the practice. Matching the problem and solution is key because the ways in which a problem is understood and represented influence its solution (Simon, 1996).

Moreover, any action research study is positioned in the context of a study that provides the conditions that give direction and constrain the research. The study context is framed by the purpose of the research and the knowledge interest of the researcher. Further, the positionality and structure of the relationship between researchers and practitioners provide restrictions on knowledge creation. For instance, being an outside researcher might entail more knowledge about the research system and less power to influence and understand the practice system that is being studied. Additionally, a researcher with a mainly technical knowledge interest might be more focused on the solutions than on identifying the problem.

The two dimensions of research and practice generate four different elements that need to be considered:

- Problem identification: This component includes the identification, representation and relevance of the practical problem. Problems are rooted in their social and cultural background, so the researcher needs to move toward the specific problems encountered in particular cases. The goal is to identify a researchable problem.

- Theorization: The process of theorizing is concerned with understanding, defining and theoretically refining the practical problem. Plausible theoretical ideas are developed as a means for linking the problem to the development of guiding concepts that may solve it. Theorization is linked to critical, constructive theorization rather than providing normative models of how to do things in organizations.

- Creating guiding concepts: This element concerns the development of the ideas that may be tested in practice. Guiding concepts are thus representations of the concepts and general rules that may help to solve the practical problem. These guiding concepts may be developed by the researcher or identified in previous work. For instance, process mapping or service recovery models may be viewed as guiding concepts that support developing more effective organizations.

- Intervention: This element includes the action component of action research where ideas are tested in specific contexts.

The framework should be understood as an attempt toward understanding the various aspects that constitute action research projects rather than as a normative process model for conducting action research (e.g. planning, acting, observing and reflecting). Even though all elements are part of any action research project, they may not be explicitly addressed. For instance, organizational change projects tend to be undertheorized and miss the underlying theories explaining why change happens (Beer and Nohria, 2000). A central use of the analytical framework in the present study is the illumination of the existence of different approaches to action research in 
service research in terms of theorization, creation of guiding concepts and interventions.

\section{Method}

\subsection{Literature review approach}

The literature review built a foundation (Feldman, 2007) for understanding the use of action research in service research. The first phase of the review is the identification of potential papers of interest using a set of inclusion criteria beginning with determining the time span and subject area of the considered journal publications. Contrary to other studies that investigate well-established methods that have reached a certain level of maturity (Barratt et al., 2011), there seems to be no commonly accepted milestone of maturity for the use of action research in service research. Given this emerging nature of the phenomena, a timespan of 20 years was used in the review, and the journal subject areas were kept open-ended. Further, the study limited the main source of evidence to academic journals. Accordingly, "gray" literature, such as conference proceedings and book chapters, were excluded. The main search was performed in Scopus and the Web of Science in October 2018. Building on Torraco (2016, p. 418), who suggests that the criteria for selecting literature must be "broad enough to capture the breadth of relevant literature," the following search strings were used:

- Scopus: (TITLE-ABS-KEY (“action research" OR "collaborative research" OR "interactive research") AND
TITLE-ABS (service) AND TITLE-ABS (manage*)) AND PUBYEAR > 1997 AND (LIMIT-TO (DOCTYPE, “ar”) OR LIMIT-TO (DOCTYPE, “re”) OR LIMIT-TO (DOCTYPE, “ip”)) AND (LIMIT-TO (LANGUAGE, "English")); and

- Web of Science: (TS = "“action research" OR "collaborative research" OR "interactive research") AND $\mathrm{TS}=$ (service) $\mathrm{AND}$ TS $=\left(\right.$ manage $\left.^{*}\right)$ ) AND LA = (English) AND DT $=$ (Article OR Early Access OR Review).

Although the search strategy includes a potentially broader scope of journals than those that are immediately associated with service research and the recent literature reviews therein (Keating et al., 2018; Raddats et al., 2019), action research has already gained a position in fields related to service research, in which the journal titles are associated with fields such as healthcare (Meyer, 2000) and operations management (Coughlan and Coghlan, 2002); the inclusion of these fields will strengthen the review. In addition to the main search, a list of service research-based journals ("service") were searched for "action research" in all search fields, resulting in five additional papers included (Figure 1).

The structuring of the review of the papers was staged (Torraco, 2005) and guided by the steps for a systematic review proposed in Prisma (Moher et al., 2009), as shown in Figure 2. To combine this search with the analysis of various approaches to action research, the framework development, structured review/

Figure 2 Prisma flowchart for the systematic literature review process
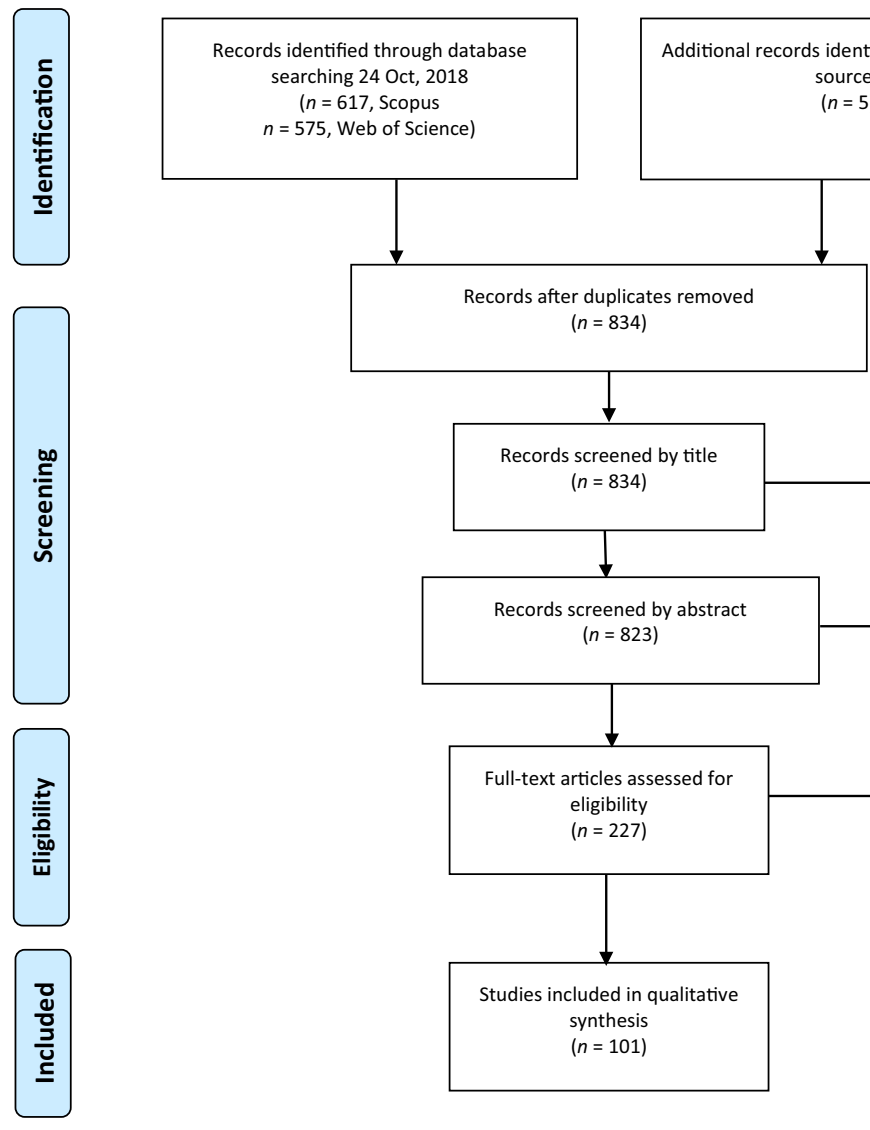

Additional records identified through other sources $(n=5)$

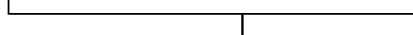


analysis of the literature and writing literature review steps in Prisma were completed by following the procedures suggested by Barratt et al. (2011), Nolan and Garavan (2016) and Torraco (2016).

Two authors screened all abstracts by paper title, journal title and keyword with the study purpose and the conceptual boundaries in mind. In addition, a list of service research-based journals ("service") were searched for "action research" in all search fields, resulting in five additional papers being included (Figure 2).

\subsection{Framework development, review and analysis}

The full text of the reviewed papers were coded using a framework (Table I) that was developed both deductively (certain coding criteria were adapted from Barratt et al. (2011), Nolan and Garavan (2016) and Siva et al. (2016) and inductively (in line with the topic and purpose of this paper).

The reviewed papers are clustered into three main action research approaches based on the reported outcomes: practiceenhancing, concept developing and theory-enhancing. Practice-enhancing is characterized by focusing on the outcomes related to the solution in a specific practical system (Figure 1), i.e. descriptive insights, examples or ideas (coding criteria as in Table I). The concept developing approach focuses on the solution but with outcomes directed at the research system, which are the models and guidelines (Table I).

Table I Coding framework

\begin{tabular}{|c|c|}
\hline Coding criteria & Description of code \\
\hline Year & $\begin{array}{l}\text { The year in which the paper was published in the } \\
\text { journal }\end{array}$ \\
\hline Relevance & $\begin{array}{l}\text { Relevance to the study based on the journal title, } \\
\text { paper title, abstract, keywords and reading of the } \\
\text { paper }\end{array}$ \\
\hline Sector studied & Empirical context, private B2C or B2B or public \\
\hline Type of paper & Conceptual/theoretical or conceptual \\
\hline Research strategy & Qualitative, quantitative or mixed methods \\
\hline $\begin{array}{l}\text { Data collection } \\
\text { method }\end{array}$ & $\begin{array}{l}\text { For example, observation, focus groups and } \\
\text { interviews }\end{array}$ \\
\hline Researcher's role & $\begin{array}{l}\text { Insider or outsider (Coughlan and Coghlan, 2002; } \\
\text { Herr and Anderson, 2014; Sandberg and Wallo, } \\
\text { 2013; Svensson et al., 2007) }\end{array}$ \\
\hline Proximity & $\begin{array}{l}\text { The extent to which the researcher and practitioner } \\
\text { collaborate in problem formulation, analysis, } \\
\text { application/use and writing (Nielsen and Svensson, } \\
\text { 2006; Baskerville and Wood-Harper, 1996; Brydon- } \\
\text { Miller et al., 2003; Sayer, 2010) }\end{array}$ \\
\hline Outcome & $\begin{array}{l}\text { Model, proposition, ideas, guidelines, descriptive } \\
\text { insights, theoretical framework, research agenda, } \\
\text { examples and new knowledge (developed from } \\
\text { Barratt et al., 2011; Siva et al., 2016) }\end{array}$ \\
\hline Quality criteria & $\begin{array}{l}\text { Explicitly stated, and, if so, what type of validity } \\
\text { (dialogic, outcome, catalytic, democratic, process, } \\
\text { other; Herr and Anderson, 2005) }\end{array}$ \\
\hline Knowledge interest & $\begin{array}{l}\text { Epistemological characteristics in terms of } \\
\text { Habermasian knowledge interests (technical, } \\
\text { practical/communicative or emancipation; } \\
\text { Habermas, 1972) }\end{array}$ \\
\hline
\end{tabular}

Finally, the theory-enhancing approach concerns the research system and the problem, with propositions, new knowledge, research agendas and theoretical frameworks as its main outcomes (Table I).

Prior to the analysis, the authors discussed one of the papers that was included in the review and then coded five papers independently to calibrate the review approach and enhance the intercoder reliability. All four researchers were involved in the review and coding of the papers. The validation of coding was conducted by the research team (Siva et al., 2016), including assessing the inter-rater reliability, cross-comparison of results and re-evaluation of papers to record data (Nolan and Garavan, 2016). One researcher coordinated this work and ensured that all authors shared in the discussions about interpretation and borderline cases.

\section{Findings}

The first part of the findings comprises a descriptive analysis of the papers, including the sector studied. The second part focuses on the ways in which action research is associated with different types of knowledge interests. To further understand the approaches to action research and their underlying rationale, the third part highlights the forms of collaboration between the researchers and practitioners. Finally, the fourth part addresses the use of research quality criteria in the reviewed papers.

\subsection{Descriptive analysis}

The publications on action research in service research have increased over the years and investigated services in a variety of industries, such as software (Barqawi et al., 2016), logistics (Eirill and Hammervoll, 2010), manufacturing (McAdam et al., 2016) and public sector organizations, like local healthcare and social services (Valokivi, 2004), family drug courts (Kovach et al., 2017) and inpatient mental health services (Larkin et al., 2015). In total, the reviewed papers concern B2B (24 per cent), B2C (17 per cent) and public sector organizations ( 58 per cent).

In addition to being varied in terms of their empirical context, the reviewed papers span a wide range of research problems and have produced a variety of outcomes. Examples of these outcomes are tools to develop and communicate a service development strategy (Lüftenegger et al., 2017), cost models (Kullven and Mattsson, 1994) and a process for improved information sharing (Kovach et al., 2017). The two most common types of outcomes are practical guidelines that are built by the study and what is referred to here as descriptive insights (Barratt et al., 2011). Examples of guidelines are a workbook and tools to support supply strategy decision-making (Walker et al., 2008), a step-by-step guide to implementing partnerships (Zybell, 2013) and descriptions of how to implement a new pricing approach (Calabrese and Corbo, 2015). Descriptive insights can be exemplified by Elg et al. (2012) who describe how an intervention affected how the studied clinic-handled patient information and Josif et al. (2012) who describe improvements in the discharge process of a regional hospital.

Only a few papers present propositions, theoretical frameworks or research agendas as part of the research 
outcomes. One of the exceptions is the work of Smith et al. (2018) that outline propositions for the priorities that are needed to support lean implementations, e.g. the customization of the lean approach to the context of each organization. Other examples are a theoretical framework for an analysis of change (Walker et al., 2008) and a research agenda to support the operationalization of S-D logic at a strategic level (Lüftenegger et al., 2017). As outlined in Section 3.2 , the types of outcomes reported form the basis for three approaches to action research: practice-enhancing, concept developing and theory-enhancing. The following sections will present the findings based on these approaches.

\subsection{Underlying knowledge interests}

With respect to the three types of knowledge interest (Habermas, 1972; Granero-Molina et al., 2015), most of the reviewed papers focus on technical knowledge interest and use empirical data to explain and analyze frameworks or models that were derived from earlier research. The second most common is practical knowledge interest, which is followed by the least common of the three, emancipatory knowledge interest.

For papers on practice-enhancing action research, there is a focus on the contributions to practice and practical knowledge interest is more common here than in the other two approaches to action research. One example is the paper by Gylling et al. (2012) that explores the use of narratives to create shared meanings in an organization as a way of overcoming poor service quality. Also focusing on service quality, Hill et al. (2016) is an example of a paper with a strong practical knowledge interest in the context of a maximum security prison. However, Hill et al. (2016) also show the traits of technical and emancipatory knowledge interests. Among the few papers with a clear emancipatory knowledge interest, one example is Dawson et al. (2014), which is a study on utilizing storytelling to support a change process for elderly and disabled patient care.

The concept developing approach has a clear dominance for one type of knowledge interest, namely, the technical. This is natural, as the most common outcomes are guidelines or models based on a planned intervention, e.g. developing a performance measurement system for ground handling services (Schmidberger et al., 2009) or supporting the transformation of a small- and medium-sized enterprise toward becoming a product-service solution provider (Clegg et al., 2017). The latter is an example of the use of action research as one step in a transformation in which a new shared meaning is needed, and this is a type of paper that is common in studies displaying a practical knowledge interest. A final example of a clear practical knowledge interest is Lim et al. (2018, p. 99) that contributes by "creating real change in organizations together with practitioners, thereby adding to scientific knowledge about practice".

With respect to the theory-enhancing approach, a variety of knowledge interests are displayed in descending order from technical, practical and emancipatory interests. Some papers display both a technical and practical knowledge interest concerning the implementation of a somewhat predefined concept, e.g. lean implementation in IT services (McAdam et al. (2016) or the development and implementation of a supply strategy (Walker et al. (2008). Examples of papers with this approach to action research and emancipatory interests are Smith et al. (2018), which focuses on the empowerment of frontline service employees, and Calabrese and Corbo (2015), which describes implementation of total quality management in a service organization.

\subsection{Proximity and interactions between researchers and practitioners}

The proximity between researchers and practitioners can be studied by identifying the phases of a research process in which collaborations between researchers and practitioners occur. The collaborations in papers were coded in four stages of the research process: problematization, analysis, application and writing. Overall, the most common stage in which researchers collaborate with practitioners is in the application of results, which is followed by collaborations in the data analyses. To a lesser extent, there is collaboration in the problematization during a study's design, and very few papers are collaboratively authored. In the study by Smith et al. (2018, p. 286) that uses a theory-enhancing approach to action research, the usefulness of this close relation and high degree of involvement is put forth:

[...] emphasis on the Lean philosophy, again possibly enabled by the action research approach and the involvement of the research team. Here, the "respect-for-human" elements were strongly enforced through such things as the inclusion of employees in the Lean implementation and the consideration of the role of employees within the revised operation.

Further, practice-enhancing papers are closely related to nonresearcher stakeholders, illustrated as follows (Pagoropoulos et al., 2017): "researchers did not assume a passive role, but were actively influencing processes and activities in the company, helping the participating companies achieve their common goals" (p. 373).

As action research naturally entails a high degree of proximity between researchers and practitioners, a clear majority of the papers are based solely on qualitative data (for all action research approaches). Further, data are often collected by multiple methods. However, a commonality across the three action research approaches is that interviews are the main data collection method (used in more than 70 per cent of the papers), and that observations are also common across all approaches and used in about half of the papers reviewed. It can also be noted that the practice-enhancing approach is characterized by the broadest range of methods and is the approach with the highest percentage use of surveys. In some cases, surveys that are used in the different approaches serve different functions in relation to the research process. In their practice-enhancing approach, Fletcher et al. (2008, p. 454) used a survey to evaluate the intervention by sending a "short postal survey of participants who attended any of the three learning sessions [...] after the final learning session." Further, in their theory-enhancing approach, Stanworth et al. (2015, p. 466) used surveys of critical incidents prior to an intervention to create "insights that stimulated reflection on action that underpinned two further iterations of action research." Last, the practice-enhancing approach differs, in that the second-most common data collection methods are not observations (as with the other two approaches) but focus groups. This can be an indication of the proximity between researcher and practitioners and the movement from 
observations to group-based collaborative efforts, which also influences how to address and enhance the research quality.

\subsection{Research quality}

The research quality criteria in action research focuses on the quality of the outcome and on the quality of the researcherparticipant interactions. Interestingly, only a quarter of the papers reviewed addressed the research quality criteria explicitly, and only a few were conducted using the AR-specific criteria suggested by Herr and Anderson (2005), such as dialogic and process validity or democratic validity. When explicitly addressed, research quality was either addressed through a description of the action research process or by referencing criteria not specific to action research such as credibility, transferability, dependability, confirmability (Lavikka et al., 2009), truthfulness and reflexivity (Fieldhouse, 2012), while others explicitly limited the generalizability and transferability of their findings (Stanworth et al., 2015; Razmdoost and Mills, 2016). Interestingly, despite the processual nature of action research and service research, the quality criteria addressing the processes are less apparent than the criteria concerning the research outcomes. Among the specific quality criteria for action research (Herr and Anderson, 2005), the most apparent is the validation of the research achievements, that is, the outcome validity and democratic validity focused on the results being relevant to a local setting. For example, the study by Adebanjo et al. (2013) on supplier selection in developing economies provides an elaborate discussion on the relevance and impact of the findings in the local context in relation to the study's validity. Meanwhile, while theory-enhancing represents the research contributions closest to theory development, the discussion of research quality is largely absent in these articles. In contrast, for the practice-enhancing approach where the focus is on the application to and impacts on the practice, which means that the results are of greater interest to the participants than the researchers, there are more apparent discussions of the research quality.

\section{Discussion}

Action research, with its focus on both the practical concerns of people in problematic situations and collaborative science, could be an approach for theory development by conducting research that is characterized by the simultaneous creation of practical and theoretical value. However, while action research seems to be a good methodological fit (Edmondson and Mcmanus, 2007) and entails conceptual synergies with the cocreative and situational features of services, its actual application is often non-systematic, in that a number of studies claim to follow an action research approach but do not adhere to many of the key principles and practices. In particular, while the service field has responded to the call to be more relevant to practice by developing new theoretical directions, i.e. suggesting what to study, this has not always been met by corresponding methodological advancements, which are concerned with how to advance new knowledge. The following discussion elaborates upon this discrepancy by first the three action research approaches and their relations to the four elements of problematization, theorization, guiding concepts development and intervention, which in turn help address three gaps preventing greater usage of action research for service research. A second path to address this discrepancy is through enhancing the usage of research quality criteria, which are specific to action research in the field of service research.

\subsection{Three approaches to service action research}

To answer the research question on how the usage of action research in service research can be characterized, the reviewed papers can be divided into three approaches: practiceenhancing, concept developing and theory-enhancing. While each approach is unique in terms of its focus on certain outcomes, they also serve as illustrations for enhancing the potential of action research in the context of service research by overcoming three gaps: knowing-doing, access and skill gap.

First, one key purpose of action research is bridging the knowing-doing gap between research and practice, through which the usability of theories may be illustrated by using welldesigned action research studies that result in implications for both practical and theoretical developments. Second, the access gap is demonstrated by most reviewed papers not fully exploiting the potential of working in teams, which provide close proximity between both researchers and practitioners. Fully maximizing the action research's potential access to micro-processes in organizations is needed so that the researcher can grasp the essential details in the management and organization of services. Finally, from the review, a skill gap can be noted in how researchers and practitioners work in close proximity and in their ability to both investigate and release the potential of service research. In other words, skills are needed to fully exploit the conceptual intersectionality of action research and service research to advance knowledge creation. Table II provides an overview of these three gaps with respect to the three approaches to action research in service research. Derived from these two dimensions in the table and the coding framework used for analysis (Figure 1), distinct features are depicted in the main body of the table that serve not only as descriptors helping researchers to characterize their specific research design but also as proposals for how to enhance the potential for action research.

The practice-enhancing approach concerns the outcomes that are relevant to the specific context of the action research study, e.g. information-intensive services (Lim et al., 2018) or primary care (Fletcher et al., 2008). Although there is sometimes a tendency for retrofitting (i.e. practical work that is retrospectively framed in action research terminologies), there are examples that truly embed their work in articulated action research frameworks. Gravesteijn and Wilderom (2018) is one example in which collective reflections between different actors took place throughout the studied change process. This is also in line with practice-enhancing being an approach that is characterized by close proximity between researcher and practitioners, such as that seen in the significant use of both focus groups and observations. A bit contradictory to this is that practice-enhancing is characterized mainly by technical and practical knowledge interests rather than by an emancipatory one, which could have been expected given the focus on the outcomes in a specific setting. Eden and Huxham (1996) point out that action research projects need to have implications beyond the generation of knowledge in the specific setting: 
Table II Three approaches to action research in service research

\begin{tabular}{|c|c|c|c|}
\hline Approach features & Practice-enhancing & Concept developing & Theory-enhancing \\
\hline $\begin{array}{l}\text { Knowing-doing: } \\
\text { analytical focus }\end{array}$ & $\begin{array}{l}\text { Evaluation of "what works" in the } \\
\text { studied context }\end{array}$ & Identifying broad normative implications & Extracting theoretical links and relations \\
\hline $\begin{array}{l}\text { Knowing-doing: } \\
\text { outcomes }\end{array}$ & $\begin{array}{l}\text { Descriptive insights, examples or } \\
\text { ideas }\end{array}$ & Models and guidelines & $\begin{array}{l}\text { New knowledge, research agendas and } \\
\text { theoretical frameworks }\end{array}$ \\
\hline $\begin{array}{l}\text { Knowing-doing: } \\
\text { challenges to } \\
\text { overcome }\end{array}$ & $\begin{array}{l}\text { Too much involvement in practical } \\
\text { affairs }\end{array}$ & $\begin{array}{l}\text { Developing concepts derived from earlier } \\
\text { research without sufficient analysis of problem- } \\
\text { solution match }\end{array}$ & Theory development removed from reality \\
\hline $\begin{array}{l}\text { Access: } \\
\text { collaboration }\end{array}$ & $\begin{array}{l}\text { Proximity to those who experience } \\
\text { and know the problem }\end{array}$ & $\begin{array}{l}\text { Methods experts and people working with } \\
\text { development in organizations } \\
\text { Reciprocal learning }\end{array}$ & $\begin{array}{l}\text { Knowledge experts in relevant disciplines and } \\
\text { functions }\end{array}$ \\
\hline $\begin{array}{l}\text { Access: research } \\
\text { quality criteria }\end{array}$ & $\begin{array}{l}\text { Democratic validity, outcome } \\
\text { validity, catalytic validity, process } \\
\text { validity }\end{array}$ & $\begin{array}{l}\text { catalytic validity, democratic validity, process } \\
\text { validity }\end{array}$ & Dialogic validity and process validity \\
\hline Skills: researcher & Systematic intervention methods & Using management methods and concepts & $\begin{array}{l}\text { Creative and reflective skills } \\
\text { Broad repertoire in method and theory }\end{array}$ \\
\hline Skills: positionality & $\begin{array}{l}\text { Advantageous to insiders to } \\
\text { ensure sustained focus on the } \\
\text { practice system }\end{array}$ & $\begin{array}{l}\text { Balancing insiders and outsiders researcher- } \\
\text { practitioner support and mentoring is } \\
\text { bidirectional }\end{array}$ & $\begin{array}{l}\text { Advantageous to outsiders to ensure sustained } \\
\text { focus on the research system }\end{array}$ \\
\hline $\begin{array}{l}\text { Examples of } \\
\text { service studies }\end{array}$ & Improving poor service quality & Service blueprinting & $\begin{array}{l}\text { Exploit conceptual synergies; e.g. service } \\
\text { improvement process closely related to the } \\
\text { research process }\end{array}$ \\
\hline
\end{tabular}

It must be possible to envisage talking about the theories developed in relation to other situations. Thus, it must be clear that the results could inform other contexts, at least in the sense of suggesting areas for consideration (Eden and Huxham, 1996, p. 78).

Thus, for service researchers performing action research, the findings should be generalized by integrating the service concepts in their context and discussing the applicability of the results to other contexts. By doing this, the features of action research can become a means of advancing both theoretical developments and practical relevance ( $\mathrm{Ng}$ and Vargo, 2018; Brodie and Gustafsson, 2016), i.e. a means of bridging the knowing-doing gap.

While the concept developing approach concerns the research system, in that it often focuses on evaluating existing models/concepts in new contexts, the researcher is also dependent on good access to and collaboration with practitioners. This is emphasized by $\mathrm{Ng}$ and Vargo (2018) as follows:

The role of the researchers was to support, mentor, educate, empower and organize - to provide structure around their process, and provide them resources and tools. The outcome was different in each community, as required to meet their unique needs (p. 68).

However, as an approach, concept developing is often driven by a general technical knowledge interest using empirical data to explain and analyze frameworks or models that are derived from earlier research rather than the needs of a specific context. Here, action research resumes the role of supporting the transformation that is needed in a certain practice setting when implementing a new concept, e.g. a performance measurement system (Schmidberger et al., 2009) or lean manufacturing (LaGanga, 2011). The focus on the practical problem is shown, in that the technical knowledge interests are dominant in the concept developing approach. In general, there is much action research that has a practical purpose with aspirations for change and for informing the reflective practitioner (Kemmis, 2006).
This is clearly reflected in the type of research outcome (guidelines and models), which are dominated by instrumental rather than conceptual relevance (Nicolai and Seidl, 2010). The extent of the proximity and role of researcher in the process (ibid) also leaves room for more intense interactions and mutual learning, which indicates that action research in service research is predominated by instrumental relevance. Conceptual relevance, on the other hand, requires a more distinct reciprocal learning process between practitioners and researchers. Hence, the access gap needs to be overcome by increased proximity and truly engaged researchers (either insider or outsider).

The technical and practical foci are, however, not an excuse for not addressing the theoretical aspects and not exploiting the potential for service action research to make theoretical contributions. The theory-enhancing approach serves as an example of that. Examples of theoretical contributions are the propositions related to lean that were put forth by Smith et al. (2018) and the change analysis framework of Walker et al. (2008). It is notable that in these theoretical contributions, conceptual synergies of service research and action research are clear. In Walker et al. (2008), for example, the process of strategizing is closely related to the process of researching. The special characteristics of this action research process such as proximity, flexible interactions and a broad range of data collection methods require a highly qualified research team. Additionally, the potential depth of the knowledge interest requires skills that are not bound to the instrumental use of methods. Our findings indicate, however, that most action research projects are carried out by outsiders, rather than by those from within the studied organizations. This can be a matter of access but also reflects a certain skill gap. To further action research in service research, researchers, therefore, need to have broad spectra of skills to cope with the uncertainty of 
the how the research unfolds. Such skills involve conceptual creativity, social skills, genuine collaborative interests and finally, broad knowledge and interests in practitioners' specific problems.

\subsection{Enhancing research quality in service action research}

More than 20 years ago, Eden and Huxham (1996) highlighted the necessity for management action researchers to extend their consultancy roles by being reflective and self-aware. Their ideas of emerging theories adopted an inductive approach. Although this is one possible path in service action research, it appears that most researchers follow an abductive process (Alvesson and Sköldberg, 2017) where they apply and adjust theories in relation to new practical insights throughout an action cycle (Argyris and Schon, 1978; Healy and Perry, 2000). Responding to $R Q 2$ regarding how research quality is addressed and enacted in action research studies in service research, the results indicate that it is doubtful that the service research reviewed in this study follows such a reflective and iterative approach as outlined by action research. While the quality criteria specific to action research have been suggested (Herr and Anderson, 2005), a critical aspect from the reviewed articles is the variety in, and even lack of, discussion on the research quality criteria. The criteria that are most apparent in service action research are related to the achievement of research in terms of outcome validity and relevance to the local setting, i.e. democratic validity. Quality criteria that assess the process that leads to the research achievements such as process, dialogic and catalytic validity are less apparent. Given the importance of quality criteria to guiding the research design and subsequent action research study, and the lack of variety in the use of these in service action research, the meanings of the criteria need further clarification. To this end, Table III presents a summary of the recommendations for enhancing research quality in service action research.

In Table III, Columns 1 and 2 depict the criteria of Herr and Anderson (2005) and their meanings. Column 3 outlines to the choices and actions that can guide the application of the criteria, as seen from the perspective of the researcher, which are derived from the reviewed papers and the general action research literature. Dialogic and process validity are enhanced by adopting a multi-actor approach with respect to action research and service research; working in research teams and having dialogue with peers in the research community enhance the validity of the research design. With respect to the practitioner, this approach entails working with various service stakeholders, including providers, various levels of managers and users.

Table III Enhancing research quality of SAR: criteria, meaning and key choices

\begin{tabular}{|c|c|c|c|}
\hline $\begin{array}{l}\text { Quality } \\
\text { criteriaa }\end{array}$ & Goals of $A R$ and meaning $^{a}$ & Recommendations for choices and actionsb & $\begin{array}{l}\text { Example of service } \\
\text { concept }^{b}\end{array}$ \\
\hline $\begin{array}{l}\text { Dialogic } \\
\text { and process } \\
\text { validity }\end{array}$ & $\begin{array}{l}\text { The generation of new knowledge } \\
\text { The "goodness" of research, as determined by } \\
\text { peer review }\end{array}$ & $\begin{array}{l}\text { AR must be seen as a collaborative inquiry (research team) } \\
\text { Engage in reflective dialogue with peers (outside research } \\
\text { team) } \\
\text { Triangulation }\end{array}$ & $\begin{array}{l}\text { Service providers } \\
\text { Service managers } \\
\text { Multilevel view of the service } \\
\text { organization } \\
\text { Service stakeholders }\end{array}$ \\
\hline $\begin{array}{l}\text { Outcome } \\
\text { validity }\end{array}$ & The achievement of action-oriented outcomes & Results lead to desired outcome & $\begin{array}{l}\text { New supplier service } \\
\text { requirements lead to } \\
\text { transformation of the supplier } \\
\text { base }\end{array}$ \\
\hline $\begin{array}{l}\text { Catalytic } \\
\text { validity }\end{array}$ & $\begin{array}{l}\text { The education of both researcher and participants } \\
\text { Concerns the transformative potential of action } \\
\text { research } \\
\text { The research process reorients, focuses and } \\
\text { energizes participants and researchers toward } \\
\text { knowing reality to transform it (Lather, 1986) }\end{array}$ & $\begin{array}{l}\text { Open for changes: Researchers/practitioners must be open } \\
\text { to reorienting their view of reality and their own role } \\
\text { Cyclical research design: Build research design on an } \\
\text { iterative process that encourages changes in researchers'/ } \\
\text { participants' understandings. Keep a journal or a protocol, } \\
\text { recording actions and changes. Example: Collect and } \\
\text { evaluate process data before and after process redesigns }\end{array}$ & $\begin{array}{l}\text { Service process redesign } \\
\text { Service improvements }\end{array}$ \\
\hline $\begin{array}{l}\text { Democratic } \\
\text { validity }\end{array}$ & $\begin{array}{l}\text { Results are relevant to the local setting/the needs } \\
\text { of the problem context } \\
\text { ". . .the extent to which research is done in } \\
\text { collaboration with all parties who have a stake in } \\
\text { the problem under investigation" }\end{array}$ & $\begin{array}{l}\text { Protocols proofread, discussed and agreed upon by all } \\
\text { parties } \\
\text { Reflection and feedback sessions with relevant } \\
\text { participants } \\
\text { A series of small/incremental tests rather than one test at } \\
\text { the end of the research process }\end{array}$ & $\begin{array}{l}\text { Service stakeholders } \\
\text { Customers and users } \\
\text { Service modularity and value } \\
\text { co-creation (require input } \\
\text { from different functions) }\end{array}$ \\
\hline $\begin{array}{l}\text { Process } \\
\text { validity }\end{array}$ & $\begin{array}{l}\text { A sound and appropriate research methodology } \\
\text { Results must be generated through cycles of } \\
\text { reflections and ongoing problematization of the } \\
\text { practices that are being studied } \\
\text { Frame and solve problems in a manner that } \\
\text { permits the ongoing learning of the individual or } \\
\text { system }\end{array}$ & $\begin{array}{l}\text { Establish good face-to-face relationships with participants } \\
\text { Take a broad view of the evidence, but define and record it } \\
\text { carefully. Relate this to how frameworks and variables } \\
\text { change during the study } \\
\text { Triangulation }\end{array}$ & $\begin{array}{l}\text { A collaborative process for } \\
\text { service improvement }\end{array}$ \\
\hline
\end{tabular}

Notes: ${ }^{a}$ Based on Herr and Anderson (2005). ${ }^{b}$ Populated based on the papers that are reviewed in this study, based on Columns 1 and 2 
Complementary to this idea is the emphasis of process validity for building good researcher-practitioner relationships, in which the face-to-face interactions in various forms are expected to enhance learning. Outcome validity, representing that the action-oriented outcome is achieved, can be expressed in service research terms, such as expressing to what extent new service requirements on suppliers transform the supplier base. Catalytic validity builds on an iterative research design and requires that both researchers and practitioners revisit their roles and views during the research process. In a service research context, participants must be open to changes when studying and acting upon items, such as service improvements and redesigning service processes. Democratic validity ensures the relevance to the local context by interacting with various participants. Inclusion of the views of participants, such as customers and service users, can be important in this respect, but concepts such as value co-creation and service modularity, which are multifunctional in nature, would require including the perspective of various service stakeholders to enhance democratic validity. Compared with the traditional quality criteria of validity and reliability in qualitative research (Healy and Perry, 2000), dialogic, process and catalytic validity firmly emphasize team-peer and researcher-practitioner interactions in research and openness to change during the research process. Interestingly, both catalytic and democratic validity are reflected in, and can be enhanced through, the service concept that is investigated exploiting the abovementioned conceptual synergies. In addition, catalytic validity through change- and action-oriented concepts, such as improvements and democratic concepts, encourage multi-actor engagement.

\section{Concluding remarks}

Responding to a call for increased relevance of research and an understanding of how to enhance research design that leads to this, this paper argues that advancement in knowledge creation in service research must be based on methodological choices that are grounded in the characteristics of services, namely, their situational and interactive nature. This approach favors the use of collaborative research designs, such as action research. To this end, theorizing becomes experiential in nature, created in the exchange space between the researcher and the practitioner.

The findings present an analytical framework outlining four elements required when designing action research projects: problem identification, theorization, creating guiding concepts and intervention. Action research deals with all these elements implicitly or explicitly to various degrees, and an intended use of the framework is to highlight the existence of different characteristics and priorities in service action research.

Following this framework, and the way by which scholars move across the research system and practice system, the paper identifies three approaches to action research in service research - practice-enhancing, concept developing and theoryenhancing - that serve as guiding principles for different types of research outcomes. To be used effectively, these approaches must be combined with the specific nature of the service concept or phenomena under study.

To get an in-depth understanding of the usage of action research in service research, this study took a broad view on the field, including marketing, management, organization studies, operations management and healthcare. Interestingly, these areas vary with respect to use of action research and existing methodological debate. Practice-enhancing is particularly apparent in medical science and health care in their focus on systematic intervention. The strong emphasis on developing normative models and guidelines in management research should be scrutinized to enhance the concept development approach. Finally, critical and reflective organizational studies serve as benchmark for those pursuing a theory-enhancing approach.

Considering the great variety in and, even, the lack of discussion of research quality, such as the validity and generalizability in a number of service action research studies, there is a need for a firmer use of research quality criteria that capture the particularities of action research. Criteria such as democratic validity and catalytic validity are suited for the multi-actor and interactive nature of action research and correspond well to the similar characteristics of service concepts, such as value co-creation, service stakeholders and service improvements.

\section{References}

Adebanjo, D., Ojadi, F., Laosirihongthong, T. and Tickle, M. (2013), "A case study of supplier selection in developing economies: a perspective on institutional theory and corporate social responsibility", Supply Chain Management: An International fournal, Vol. 18 No. 5, pp. 553-566.

Alvesson, M. and Spicer, A. (2012), "Critical leadership studies: the case for critical performativity", Human Relations, Vol. 65 No. 3, pp. 367-390.

Alvesson, M. and Sköldberg, K. (2017), Reflexive Methodology: New Vistas for Qualitative Research, Sage, London.

Alvesson, M., Gabriel, Y. and Paulsen, R. (2017), Return to Meaning: A Social Science with Something to Say, Oxford University Press, Oxford.

Argyris, C. and Schon, D. (1978), Organizational Learning: A Theory of Action Approach, Addison Wesley, Reading, MA.

Bäckstrand, J. and Halldórsson, Á. (2019), "Engaged scholar (ship) in purchasing and supply management (PSM): creative tension or squeezed in the middle?", fournal of Purchasing and Supply Management, Vol. 25 No. 4, pp. 1-14.

Ballantyne, D. (2004), “Action research reviewed: a marketoriented approach", European Fournal of Marketing, Vol. 38 Nos 3/4, pp. 321-337.

Barqawi, N., Syed, K. and Mathiassen, L. (2016), “Applying service-dominant logic to recurrent release of software: an action research study", fournal of Business $\mathcal{E}$ Industrial Marketing, Vol. 31 No. 7, pp. 928-940.

Barratt, M., Choi, T.Y. and Li, M. (2011), "Qualitative case studies in operations management: trends, research outcomes, and future research implications", Fournal of Operations Management, Vol. 29 No. 4, pp. 329-342.

Baskerville, R.L. and Wood-Harper, A.T. (1996), "A critical perspective on action research as a method for information systems research", fournal of Information Technology, Vol. 11 No. 3, pp. 235-246. 
Beer, M. and Nohria, N. (2000), "Cracking the code of change", Harvard Business Review, Vol. 78 No. 3, pp. 133-141.

Bradbury, H., Mirvis, P., Neilsen, E. and Pasmore, W. (2008), "Action research at work: creating the future following the path from Lewin", in Reason, P. and Bradbury, H. (Eds), The SAGE Handbook of Action Research: participative Inquiry and Practice, Sage Publications, London, pp. 77-92.

Bradbury-Huang, H. (2010), "What is good action research? Why the resurgent interest?", Action Research, Vol. 8 No. 1, pp. 93-109.

Brax, S.A. and Visintin, F. (2017), "Meta-model of servitization: the integrative profiling approach", Industrial Marketing Management, Vol. 60, pp. 17-32.

Brodie, R.J. and Gustafsson, A. (2016), "Enhancing theory development in service research", Fournal of Service Management, Vol. 27 No. 1, pp. 2-8.

Brydon-Miller, M., Greenwood, D. and Maguire, P. (2003), "Why action research?", Action Research, Vol. 1 No. 1, pp. 9-28.

Calabrese, A. and Corbo, M. (2015), "Design and blueprinting for total quality management implementation in service organisations", Total Quality Management \& Business Excellence, Vol. 26 Nos 7/8, pp. 719-732.

Clegg, B., Little, P., Govette, S. and Logue, J. (2017), "Transformation of a small-to-medium-sized enterprise to a multi-organisation product-service solution provider", International Fournal of Production Economics, Vol. 192, pp. 81-91.

Corus, C. and Saatcioglu, B. (2015), "An intersectionality framework for transformative services research", The Service Industries fournal, Vol. 35 Nos 7/8, pp. 415-429.

Coughlan, P. and Coghlan, D. (2002), "Action research for operations management", International fournal of Operations E Production Management, Vol. 22 No. 2, pp. 220-240.

Dawson, P., Sykes, C., McLean, P., Zanko, M. and Marciano, H. (2014), "Stories affording new pathways: bridging the divide between aged and disability care", fournal of Organizational Change Management, Vol. 27 No. 5, pp. 819-838.

Eden, C. and Huxham, C. (1996), "Action research for management research", British fournal of Management, Vol. 7 No. 1, pp. 75-86.

Edmondson, A.C. and Mcmanus, S.E. (2007), "Methodological fit in management field research", Academy of Management Review, Vol. 32 No. 4, pp. 1246-1264.

Eirill, B. and Hammervoll, T. (2010), "Cost-based pricing of transportation services in a wholesaler-carrier relationship: an MS excel spreadsheet decision tool", International fournal of Logistics Research and Applications, Vol. 13 No. 3, pp. 197-210.

Elg, M., Engström, J., Witell, L. and Poksinska, B. (2012), "Co-creation and learning in health-care service development", Fournal of Service Management, Vol. 23 No. 3, pp. 328-343.

Feldman, A. (2007), "Validity and quality in action research", Educational Action Research, Vol. 15 No. 1, pp. 21-32.

Field, J.M., Victorino, L., Buell, R.W., Dixon, M.J., Goldstein, S.M., Menor, L.J. and Zhang, J.J. (2018), "Service operations: what's next?", fournal of Service Management, Vol. 29 No. 1, pp. 55-97.

Fieldhouse, J. (2012), "Community participation and recovery for mental health service users: an action research inquiry", British Fournal of Occupational Therapy, Vol. 75 No. 9, pp. 419-428.

Fisk, R.P.P., Anderson, L., Bowen, D.E., Gruber, T., Ostrom, A., Patrício, L. and Sebastiani, R. (2016), "Billions of impoverished people deserve to be better served: a call to action for the service research community", Fournal of Service Management, Vol. 27 No. 1, pp. 43-55.

Fletcher, J., Gavin, M., Harkness, E. and Gask, L. (2008), “A collaborative approach to embedding graduate primary care mental health workers in the UK national health service", Health $\mathcal{E}$ Social Care in the Community, Vol. 16 No. 5, pp. 451-459.

Granero-Molina, J., Fernández-Sola, C., Terrón, J.M.M. and Torres, C.A. (2015), "Habermasian knowledge interests: epistemological implications for health sciences", Nursing Philosophy, Vol. 16 No. 2, pp. 77-86.

Gravesteijn, M. and Wilderom, C.P.M. (2018), "Participative change toward digitalized, customer-oriented continuous improvements within a municipality", fournal of Organizational Change Management, Vol. 31 No. 3, pp. 728-748.

Greenwood, D.J. and Levin, M. (1998), "Action research, science, and the co-optation of social research", Studies in Cultures, Organizations and Societies, Vol. 4 No. 2, pp. 237-261.

Gummesson, E. (2000), Qualitative Methods in Management Research, Sage Publications, Thousand Oaks, CA.

Gummesson, E. and Gronroos, C. (2012), "The emergence of the new service marketing: Nordic school perspectives", Fournal of Service Management, Vol. 23 No. 4, pp. 479-497.

Gummesson, E., Kuusela, H. and Närvänen, E. (2014), "Reinventing marketing strategy by recasting supplier/ customer roles", fournal of Service Management, Vol. 25 No. 2, pp. 228-240.

Gylling, C., Elliott, R. and Toivonen, M. (2012), “Co-creation of meaning as a prerequisite for market-focused strategic flexibility", European fournal of Marketing, Vol. 46 No. 10, pp. 1283-1301.

Habermas, J. (1972), Knowledge and Human Interests, Beacon Press, Boston.

Healy, M. and Perry, C. (2000), "Comprehensive criteria to judge validity and reliability of qualitative research within the realism paradigm", Qualitative Market Research: An International fournal, Vol. 3 No. 3, pp. 118-126.

Heron, J. and Reason, P. (2001), "The practice of co-operative inquiry: research 'with' rather than 'on' people", in Reason, P. and Bradbury, H. (Eds), Handbook of Action Research, Sage Publications, London, pp. 179-188.

Herr, K. and Anderson, G.L. (2005), The Action Research Dissertation: A Guide for Students and Faculty, SAGE Publications, Thousand Oaks, CA.

Hill, R.P., Capella, M.L., Rapp, J.M. and Gentlemen, G. (2016), "Antiservice as guiding maxim: tough lessons from a maximum security prison", fournal of Service Research, Vol. 19 No. 1, pp. 57-71. 
Josif, C., Barclay, L., Bar-Zeev, S., Kildea, S. and Brittin, M. (2012), "How participatory action research supported improvements to the postnatal discharge summary system used for remote dwelling aboriginal mothers and infants in the top end of Australia", Action Research, Vol. 10 No. 4, pp. 387-405.

Keating, B.W., McColl-Kennedy, J.R. and Solnet, D. (2018), "Theorizing beyond the horizon: service research in 2050", Fournal of Service Management, Vol. 29 No. 5, pp. 766-775.

Kemmis, S. (2006), "Exploring the relevance of critical theory for action research: emancipatory action research in the footsteps of Jurgen Habermas", in Reason, P. and Bradbury, H. (Eds), Handbook of Action Research, Vol. 4, Sage Publications, London, pp. 94-105.

Kovach, J.V., Curiel, V., Franklin York, A., Bogard, S. and Revere, L. (2017), "Enhancing information sharing in family drug courts: a lean six sigma case study", Fuvenile and Family Court fournal, Vol. 68 No. 3, pp. 27-41.

Kullven, H. and Mattsson, J. (1994), "A management control model based on the customer service process", International Fournal of Service Industry Management, Vol. 5 No. 3, pp. 14-25.

LaGanga, L.R. (2011), "Lean service operations: reflections and new directions for capacity expansion in outpatient clinics”, fournal of Operations Management, Vol. 29 No. 5, pp. 422-433.

Larkin, M., Boden, Z.V.R. and Newton, E. (2015), "On the brink of genuinely collaborative care: experience-based codesign in mental health", Qualitative Health Research, Vol. 25 No. 11, pp. 1463-1476.

Lavikka, R., Smeds, R. and Jaatinen, M. (2009), "Coordinating the service process of two business units towards a joint customer", Production Planning \& Control, Vol. 20 No. 2, pp. 135-146.

Lim, C., Kim, M.-J., Kim, K.-H., Kim, K.-J. and Maglio, P.P. (2018), "Using data to advance service: managerial issues and theoretical implications from action research", fournal of Service Theory and Practice, Vol. 28 No. 1, pp. 99-128.

Lüftenegger, E., Comuzzi, M. and Grefen, P.W.P.J. (2017), "Designing a tool for service-dominant strategies using action design research", Service Business, Vol. 11 No. 1, pp. 161-189.

McAdam, R., Galbraith, B., Miller, K., Moffett, S. and McAdam, M. (2016), "The role of lean at the interface with between operations management and applied services within a large aerospace organisation: a boundary spanning perspective", Production Planning \& Control, Vol. 27 No. 15, pp. 1298-1311.

Meehan, J., Touboulic, A. and Walker, H. (2016), "Time to get real: the case for critical action research in purchasing and supply management", fournal of Purchasing and Supply Management, Vol. 22 No. 4, pp. 255-257.

Meyer, J. (2000), "Qualitative research in health care: using qualitative methods in health related action research", BMF, Vol. 320 No. 7228, pp. 178-181.

Moher, D., Liberati, A., Tetzlaff, J. and Altman, D.G. (2009), "Preferred reporting items for systematic reviews and metaanalyses: the PRISMA statement", PLoS Medicine, Vol. 6 No. 7 , p. 6.
Ng, I.C.L. and Vargo, S.L. (2018), "Service-dominant (S-D) logic, service ecosystems and institutions: bridging theory and practice", Fournal of Service Management, Vol. 29 No. 4, pp. 518-520.

Nicolai, A. and Seidl, D. (2010), “That's relevant! Different forms of practical relevance in management science", Organization Studies, Vol. 31 Nos 9/10, pp. 1257-1285.

Nielsen, K.A. and Svensson, L. (Eds) (2006), Action Research and Interactive Research: Beyond Practice and Theory, Shaker Publishing, Maastricht.

Nolan, C.T. and Garavan, T.N. (2016), "Human resource development in SMEs: a systematic review of the literature", International fournal of Management Reviews, Vol. 18 No. 1, pp. 85-107.

Ostrom, A.L., Parasuraman, A., Bowen, D.E., Patrício, L. and Voss, C.A. (2015), "Service research priorities in a rapidly changing context", fournal of Service Research, Vol. 18 No. 2, pp. 127-159.

Pagoropoulos, A., Maier, A. and McAloone, T.C. (2017), "Assessing transformational change from institutionalising digital capabilities on implementation and development of product-service systems: learnings from the maritime industry", fournal of Cleaner Production, Vol. 166, pp. 369-380.

Perry, C. and Gummesson, E. (2004), "Action research in marketing”, European fournal of Marketing, Vol. 38 Nos 3/4, pp. 310-320.

Raddats, C., Kowalkowski, C., Benedettini, O., Burton, J. and Gebauer, H. (2019), "Servitization: a contemporary thematic review of four major research streams", Industrial Marketing Management, Vol. 83, pp. 207-223, doi: 10.1016/j. indmarman.2019.03.015.

Razmdoost, K. and Mills, G. (2016), "Towards a service-led relationship in project-based firms", Construction Management and Economics, Vol. 34 Nos 4/5, pp. 317-334.

Schmidberger, S., Bals, L., Hartmann, E. and Jahns, C. (2009), "Ground handling services at European hub airports: development of a performance measurement system for benchmarking", International Fournal of Production Economics, Vol. 117 No. 1, pp. 104-116.

Simon, H. (1996), The Sciences of the Artificial, MIT Press, Cambridge, MA.

Siva, V., Gremyr, I., Bergquist, B., Garvare, R., Zobel, T. and Isaksson, R. (2016), "The support of quality management to sustainable development: a literature review", fournal of Cleaner Production, Vol. 138, pp. 148-157.

Smith, M., Paton, S. and MacBryde, J. (2018), "Lean implementation in a service factory: views from the frontline", Production Planning \& Control, Vol. 29 No. 4, pp. 280-288.

Stanworth, J.O., Warden, C.A. and Hsu, R.S. (2015), "The voice of the Chinese customer facilitating e-commerce encounters", International fournal of Market Research, Vol. 57 No. 3, pp. 459-481.

Svensson, L., Ellström, P.-E. and Brulin, G. (2007), "Introduction - on interactive research", International Fournal of Action Research, Vol. 3 No. 3, pp. 233-249.

Svensson, L., Brulin, G. and Ellström, P.-E. (2015), "Interactive research and ongoing evaluation as joint learning processes”, in Elg, M., Ellström, P.-E., Klofsten, M. 
and Tillmar, M. (Eds), Sustainable Development in Organizations: studies on Innovative Practices, Edward Elgar Publishing, Cheltenham, pp. 346-361.

Torraco, R.J. (2005), "Writing integrative literature reviews: guidelines and examples", Human Resource Development Review, Vol. 4 No. 3, pp. 356-367.

Torraco, R.J. (2016), "Writing integrative literature reviews: using the past and present to explore the future", Human Resource Development Review, Vol. 15 No. 4, pp. 404-428.

Touboulic, A. and Walker, H. (2016), "A relational, transformative and engaged approach to sustainable supply chain management: the potential of action research", Human Relations, Vol. 69 No. 2, pp. 301-343.

Valokivi, H. (2004), "Participation and citizenship of elderly persons: user experiences from Finland", Social Work in Health Care, Vol. 39 Nos 1/2, pp. 181-207.

Van De Ven, A.H. and Johnson, P.E. (2006), "Knowledge for theory and practice", Academy of Management Review, Vol. 31 No. 4, pp. 802-821.

Walker, H., Harland, C., Knight, L., Uden, C. and Forrest, S. (2008), "Reflections on longitudinal action research with the English national health service", fournal of Purchasing and Supply Management, Vol. 14 No. 2, pp. 136-145.

Zybell, U. (2013), "Partner management - managing service partnerships in the supply chain - a systemic perspective", International Fournal of Physical Distribution \& Logistics Management, Vol. 43 No. 3, pp. 231-261.

\section{Further reading}

Dobers, P., Strannegård, L. and Wolff, R. (2001), "Knowledge interests in corporate environmental management: corporate environmental management", Business Strategy and the Environment, Vol. 10 No. 6, pp. 335-343.

Hammersley, M. (1992), "On feminist methodology", Sociology, Vol. 26 No. 2, pp. 187-206.

Kelley, M.L., Prince, H., Nadin, S., Brazil, K., Crow, M., Hanson, G. and Smith, J. (2018), "Developing palliative care programs in indigenous communities using participatory action research: a Canadian application of the public health approach to palliative care", Annals of Palliative Medicine, Vol. 7, pp. S52-S72.
Rocco, T.S. and Plakhotnik, M.S. (2009), "Literature reviews, conceptual frameworks, and theoretical frameworks: terms, functions, and distinctions", Human Resource Development Review, Vol. 8 No. 1, pp. 120-130.

\section{About the authors}

Mattias Elg is a Professor of Quality Technology and Management, Linköping University, Sweden. He is also the Center Director at HELIX Competence Center, Linköping University. His research is concerned with conditions and models to drive service development in organizations in both the private and public sectors. Research interests include customer co-creation, sustainable development in organizations, organizational change and performance measurement practice. Mattias Elg is the corresponding author and can be contacted at: mattias.elg@liu.se

Ida Gremyr is a Professor in Quality Management at the division Service Management and Logistics in the department of Technology Management and Economics at Chalmers University of Technology, Sweden. She also holds a position as a Guest Professor at Linköping University, Sweden. Gremyr's research interests focus on service development and innovation, servitization and quality management.

Árni Halldórsson is a Professor of Supply Chain Management at the Division of Service Management and Logistics, Chalmers University of Technology, Sweden. Árni also holds a position as a Professor of Supply Chain Management and Social Responsibility at Hanken School of Economics, Finland. His research evolves around sustainable supply, energy efficiency in the supply chain, sustainable development of logistics services, service supply chains and theorizing and methodology in this fields.

Andreas Wallo is a Professor in Education, Linköping University, Sweden. He is also the Co-director of the HELIX Competence Center at the same university. His research interests include human resource development, human resource management, leadership and managerial work in organizations, workplace learning and action and interactive research. 